\title{
Political preconditions for the institutionalization of "city management" into the system of Russian municipal government
}

\author{
Vitaly Kovalev, Alexander Dyatlov ${ }^{*}$, Alexander Nechushkin \\ Southern Federal University, 344006 Rostov-on-Don, Russian Federation
}

\begin{abstract}
This article attempts to analyze the political prerequisites for institutionalizing the mechanism for electing the head of a municipality based on a competitive selection process. The relevance of this issue is due to the fact that this model of assuming the post of head of a municipality ceases to be one of the legally defined options, turning into a mandatory political and administrative order by virtue of imperative initiatives of the authorities. As a result of the study, the authors came to the conclusion that the institution of competitive selection for appointment to the post of head of the municipality is determined by the historical political traditions of government in Russia.
\end{abstract}

\section{Introduction}

Over the past few years, the Russian Federation has been reforming the model of municipal governance. The history of the transformations of the first two decades after 1991, when the Soviet model of municipal authority was abandoned, has shown that the attempt to approach the problems in a comprehensive manner at this stage is untenable. It faces both objective difficulties and subjective misunderstanding sway on the part of territorial communities of the value and semantic occupancy of the proposed reforms. Thus, the declared values of freedom of municipal government, enshrined in the 1993 Russian Constitution, have become in many ways alien to the Russian population. Municipal elections to the authorities were not very popular, and grassroots forms of local democracy (citizens' gatherings, legal initiative, public hearings, conferences, toss, etc.) still do not cause the expected initiative to which the expected initiative, to which, is not the drafters of the Federal Law on the General Principles of Local Government Organization in the Russian Federation were calculated. As a result, the concept of municipal government as the most important structural link in the system of horizontal relations of civil society, which was to be built and structured on the basis of personal initiative of citizens, in the practice of real execution failed. The consequence of this development was another round of reforms of local government. Its target priorities have begun to shift from the expectations of the social development of the territories by stepping up through horizontal channels the personal initiatives of all interested segments of the local population (voters,

*Corresponding author: avdyatlov@yandex.ru 
business communities, political activists, political parties, local cultural figures) to use the resources of the power vertical, built by the end of the zero years at the levels of the federal and regional authorities, and ready to politically and structurally absorb themselves municipal level. As a result, the problems of democratization of local government have been sidelined, and stability and efficiency in municipal government have been identified as priorities. The most important part of the new stage of local government reform is the change in the procedure for the inauguration of the head of local government. One of the alternatives, which is promoted by the federal government as the most desirable, is the election of the head of municipal education from among the candidates submitted by the competition commission on the results of the competition. This legislative innovation, in accordance with a similar American practice, has been called by scientists as a model of "city management". Taking into account the actualization of the stated problem, we set a goal to analyze its validity and viability of traditions established in Russian society.

Article was carried out within the framework of the implementation of the RFFI grant, Project No. 18-011-01113 "Institute of City Management in Modern Russia: Administrative and Public Integrity (on the example of municipal entities of the Southern Federal District)."

\section{Literature analysis}

In the scientific community, the introduction of the procedure for the inauguration of the head of municipal education through competitive selection, contrary to the previous system of direct elections, as you would expect, has caused extremely contradictory judgments. In general, the positions of specialists, with a certain degree of assumption, can be divided into two main groups: opponents and supporters of competitive appointment.

A group of scientists who are negative about "city management" can be classified into three dominant positions, which emphasize a particular negative consequence, which is presumably due to the abandonment of the direct elections or the introduction of the appointment procedure:

1) accusation of anti-democraticism. In particular, it highlights three possible plots: (a) violation of the constitutional principle of the independence of the municipal government from the state, b) ignoring the legislative right of municipalities to choose alternative procedures the inauguration of the head of municipal education and the imposition of a competitive selection procedure convenient for the authorities, in) the construction of the power vertical by including the municipal level.

2) Assertion of managerial inefficiency. There are also three main positions: (a) detachment from the real needs and concerns of the people of the territories, the dominance of technocraticism and simulation practices, and the inability to carry out medium- and long-term planning ( The high probability of conflict between the administration and the representative body of the municipal government is high.

3) the emergence of socio-economic risks. The probabilistic implications of this paragraph focus on two aspects: (a) the withdrawal of the procedure for the inauguration of the head of municipal education from a transparent and, at the same time, legal space can stimulate the emergence of informal practices of a corrupt nature, b) the cancellation of elections excludes such a source of development of municipalities as election promises, which were previously a mechanism for obtaining funds for municipal development from federal political parties and high-status politicians.

However, the position of the proponents of the "city management" model is just as numerous and intellectually thorough. In support of its benefits and benefits, a reasoning has been put forward, which can be reduced to five main points: 
1) The separation of economic and political functions will allow managers to focus on the socio-economic issues of the development of the territories.

2) Cancellation of elections will result in savings that can be directed to other targeted expenditures.

3) Ineffective "city manager" can be dismissed early, which is difficult when the power is delegated through direct elections.

4) The absence of obligations to the population of the municipal territories will allow the "city manager" to make unpopular management decisions;

5) The cancellation of elections is a logical consequence of their transformation into an instrument of political technologies that have nothing to do with real democracy.

From the analysis of literature, we can conclude that a whole group of questions remained without proper attention. The opinion of the population itself on the abolition of the mechanism of direct elections, its exclusion from municipal policy, should be considered unexplored; the procedure and, most importantly, the possible risks of taking office as head of municipal education bypassing the opinion of territorial communities are not clear; the viability of "city management" in terms of the prospects for its development outside the existing power vertical has not been raised. In our research we propose to fill some of these loopholes by focusing our attention on the analysis of the political and administrative bases of the "city management" model in modern Russia. This will allow us to understand how deep and how long this model can exist in the system of Russian municipal government.

\section{Political-administrative meaning of the city management model}

The administrative meaning of the Russian model of city management is clearly defined in

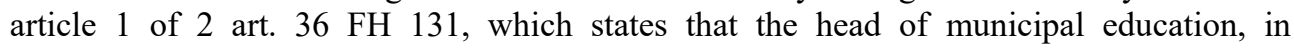
accordance with the law of the subject of the Russian Federation and the statute of municipal education, is elected in municipal elections, or by a representative body of municipal education from its membership, or a representative body of municipal education from among the candidates submitted by the competition commission on the results of the competition. The political meaning is truncated, because the federal government "strongly recommends" from the three proposed options to choose the one that determines the order of the inauguration of the head of municipal education through the competitive selection procedure.

Approval of the principle of competitive selection for the post of head of municipal education cannot be considered in isolation from the more general process of building a single power vertical of governance, which was initiated by the current President virtually with moment snares presidential election on 26 March 2000. Vladimir Putin faced many problems of different levels at that time, each of which required close attention and sometimes prompt solutions. We can now remember the high level of poverty, the lack of a social protection system, legal nihilism, weakness of power, deterioration of socioeconomic indicators of development, etc. Yeltsin.

Meanwhile, none of the tasks of that period could be solved outside the strengthening of the regime of presidential power, and not so much in the institutional aspect (the authority to implement active policy was enough yet yeltsin), but in terms of increasing the volume of resource opportunities, or, to put it more precisely and categorically, to overcome the negative challenges of the three most energetic for the turn of 1999-2000, political players: parliamentary opposition, oligarchy and national elites. Many at that time imagined that the country had a stalemate in which each of the active political actors balanced each other at the expense of equality of power and opportunity, so that society instead of moving forward 
trampled on Place. Vladimir Putin decides to eliminate this balance by dramatically increasing the resource prerogatives and political potentials of his own power. The result of this decision is the formation of a "power vertical."

In short, the model of the power vertical comes out of the idea of "managed democracy"." Perhaps with some simplification and arbitrary assumption of a number of points, its roots can be seen even in the ideas of the philosophers of the 18th century about the "enlightened monarchy". For all the external anti-democraticnature of such a concept, taking into account the specifics of Russia, where the rivalry of elites, the economic crisis, the lack of traditions of democracy, etc., the choice in favor of a political entity receiving additional the authority, whose activities are based on the trust of society, does not seem so wrong as it now seems to the Western world community. Therefore, there were no significant protests in Russia, when Vladimir Putin carried out legal reforms and political transformations in order to establish control over the main state bodies at the level of the federal and regional authorities. Without ininanying on the constitutional foundations, always staying within the legal space, the incumbent president was able to cut the "proud knot" of the political contradictions of the 1990s. 20th century due to the fact that he established administrative control over the activities of the State Duma, the Federation Council, the Prosecutor General's Office, the highest judicial authorities, as well as the relevant links at the level of the subjects of the federation.

Local authorities have long been outside the political focus of the president. Therefore, the last link of the system of government, covered by a single power vertical, can be considered the municipal level. Until relatively recently, constitutional law theorists did not consider the municipal government to be a state. It was positioned as a kind of public power, containing elements of power public and state, at the same time. The position of the lawyers has now changed. The municipal government loses its peculiarity and exclusivity in their theoretical constructions. It is no coincidence that this, the grassroots level of public relations, is included in a single system of government. This is due to the refusal of the elected beginning of the heads of administration (mayors) in favor of the appointment of "city managers". The essence of city management is that the local community is given the opportunity to refuse the popular election of the head of the administration and move to the procedure of its selection by a special competitive commission.

Supporters of the liberal model of local government are strongly criticizing the order. If we use liberal concepts from the field of constitutional law, formed on the basis of AngloSaxon political-legal traditions, it is even possible to point out the lack of legitimacy in the procedure of appointing city managers, referring to article 12 The Constitution of Russia, which declares that local self-government is not part of the system of state authorities. Meanwhile, representatives of regional government bodies are included everywhere in the competitive commissions.

It is possible to adequately assess the position of critics of the Institute of City Management only in the context of general conservative reforms taking place in our country. The power vertical itself is nothing but a etatist core for the Russian civilization under construction. The state in such a civilization is reproduced as a pillar, penetrating to all levels of social relations. The assertion of such status is connected with the dominance in the national consciousness of paternalistic values, which, being conservative by nature, because the peoples of Russia did not know the other reality of interaction between the state and society, understandable and can be accepted by the entire population in the Russian Federation.

The most important result of presidential reforms in this area can be considered the abolition of the political component in the form of a power struggle from the sphere of municipal relations. First of all, state power has in fact become a monocratic system operating on the basis of functional separation of responsibilities between power 
institutions, the work of which is carried out under the control of the President or relevant links of his Administration. The liberal principle of separation of powers, which has long been the most important criterion of democracy in assessing the functioning of state power, actually reflects a more universal view of liberalism about competitiveness socio-political and socio-economic environments of society, from which, accordingly, competition should grow in the very parts of the state system. Abandonment

the principle of competition at all levels of society in favor of a conservative notion of the paternalistic nature of power, allowing existing social perceptions on the basis of justice, led to a de facto leveling separation of powers between the three branches of the state. For paternalism, competition is equally unacceptable both in public administration and in social interactions of policy makers. The result of its abandonment was the construction of the power vertical as a necessary linchpin for modern itatist civilization in Russia. City Management was simply incorporated into this system as its organic component of the part.

\section{Conclusions}

Summing up, we can note that the implementation of the procedure of competitive selection of the head of municipal education is determined by political and administrative grounds. The inertia of public participation in real municipal management cases has in fact led to the erasure of the essential difference between municipal and state authorities. At the grassroots level of governance, the necessary horizontal links have not been established, without which social participation in governance cannot be effective. The logical consequence of this condition was the process of incorporation of the municipal management to the state. In other words, thanks to the "city-management" model, the power vertical of political power has been completed, the first two levels of which - federal and regional - have long been in the mode of "manual" management of the president. The logic and consistency of the analyzed reform of municipal government cannot but be recognized. But its effectiveness will certainly tell the time and, therefore, the assessment of its viability should invariably be the focus of the attention of researchers.

\section{References}

1. A.N. Neupreev, European Science, 5, 23-28 (2015)

2. I.V. Vydrin, Herald of the Ural Institute of Economics, Management and Law, 2, 15-22 (2011)

3. V.I. Vasilyev, Journal of Russian law, 4, 45-50 (2012)

4. L.V. Akopov, North Caucasus Legal Gazette, 3-6 (2015)

5. V.S. Avdonin, Pro Nunc. Modern political processes, 1, 21-25 (2015)

6. V.A. Ochakovsky, I.N. Ivanenko, Y.A. Krutova, V.S. Korobkov, Scientific journal Kubgau, 11, 44-48 (2015)

7. L.K. Bzegezhev, Herald of the Maykop State University of Technology, 1, 29-32(2016)

8. A.A. Shmelev, A new word in science and practice, 10, 12-16 (2014)

9. A.A. Volodin, Power, 9, 24-31 (2012)

10. N.A. Kandrina, Herald of the Altai Academy of Economics and Law, 4, 41-45(2011)

11. A.I. Sashko, Politics, the state and the law, 7, 55-58 (2014)

12. A.V. Dyatlov, P.V. Sazhin, Humanitarian, socio-economic and social sciences, 3-1, 6468 (2015)

13. A.V. Dyatlov, A.M. Kumykov, A.V. Lubsky, A.V. Serikov, O.Y. Posukhova, Mediterranean Journal of Social Sciences, 6-5, 266 (2015) 
14. A.V. Bedrik, I.P. Chernobrovkin, A.V. Lubskiy, Y.G. Volkov, N.A. Vyalykh, Indian Journal of Science and Technology, 9-5, 211-218 (2016)

15. A.V. Dyatlov, A.V. Popov, Humanitarian of the South of Russia, 6, 222-231 (2017) 